094

Received: July 24, 2009

Accepted: December 15, 2009
Macedonian Journal of Animal Science, Vol. 2, No. 2, pp. 149-153 (2012)

In print ISSN $1857-6907$

On line ISSN $1857-7709$

UDC: 636.4 .083 .3

Original scientific paper

\title{
ROLE OF BEDDING MATERIALS ON HEAT CONDUCTION LOSS CONTROL OF PIGS
}

\author{
Natalia Vllamasi Shoshi ${ }^{1}$, Pëllumb Zalla ${ }^{1}$, Etleva Veizaj ${ }^{2}$, Paulin Shoshi $^{1}$ \\ ${ }^{1}$ Faculty of Veterinary Medicine, Tirana, Albania \\ ${ }^{2}$ Faculty of Agriculture, Agricultural University of Tirana, Albania \\ natali_sh@hotmail.com
}

\begin{abstract}
Bedding materials have a significant impact on heat conductivity loss between organism and environment. The type of bedding materials can reduce in different levels the loss of heat conductivity. We are going to study the impact of bedding material on heat conductivity loss of piglets when they are kept directly on concrete surfaces, wood, plastic layers. Conductivity coefficients $(\lambda)$ were 1.1 for concrete, 0.125 for wood, and 0.250 for plastic materials. In addition, this study evaluates the importance of thickness of bedding materials on heat conductivity loss of pigs. The heat loss by conductivity on growing pigs was reduced respectively: $34 \%$ when pigs were kept in wooden materials, $59 \%$ in plastic materials. The thickness of bedding material was $25 \mathrm{~cm}$ and the temperature was $19{ }^{\circ} \mathrm{C}$ for all types of materials used. These findings are of significant importance to pig's industry husbandry.
\end{abstract}

Key words: heat loss; conductivity; growing pigs; bedding materials; reduction; husbandry

\section{УЛОГАТА НА ГРАДЕЖНИТЕ МАТЕРИЈАЛИ ВО НЕКОНТРОЛИРАНА ЗАГУБА НА ТОПЛИНАТА КАЈ СВИЊИТЕ}

\begin{abstract}
Градежните материјали имаат значително влијание врз губењето на топлината помеѓу организмот и околината. Типот на градежни материјали може да го редуцира нивото на губење на топлината. Го проучивме влијанието на градежните материјали врз губењето на топлината кај прасиња кога тие се држени на бетонски подлоги, на дрво и на пластични материјали. Коефициентот на спроводливоста на топлината ( $\lambda$ ) беше 1,1 за бетонот, 0,125 за дрвото, 0,250 за пластични материјали. Оваа студија ја потврди важноста на дебелината на материјалот употребен како подлога губењето на топлината кај свињите. Загубата на топлината поради различна термичка спроводливост изнесуваше $34 \%$ кога прасињата беа држени на дрвен материјал, а $59 \%$ кога беа држени на пластични материјали. Слојот на градежниот материјал беше 25 см, а температурата на воздухот $19^{\circ} \mathrm{C}$ за сите користени материјали. Овие резултати се од значителна важност за индустријата за одгледување свињи.
\end{abstract}

Клучни зборови: загуба на топлина; спроводливост; гојни свињи; материјали за подлога; редукција; сточарство

\section{INTRODUCTION}

In modern biology, both organism and environment make up an entirety. The external environment comprises a multitude of factors against which the individual animal or the entire flock is exposed. It exerts an impact, be it direct or indirect, on the reaction mechanisms, the yield/productivity and overall health of animals. None of the vital structures and functions of animals is able to keep at bay the impacts of environmental factors. The factors of external environment at times attempt to alter what is otherwise termed as "the internal environment of animals" or homeokineze. On the other hand, the structures and functions of the organism which sustain the "attack" environment, do not subject themselves to such actions in a passive way, but they react by coming up with a string of adequate counter-attack reactions. The animal is an open thermo-dynamical system that 
trades matter and energy with the surrounding environment.

Homeokineza is a steady condition of the organism that is determined by several dynamic and biological relative constants. The very concept of homekineze embraces- the equilibrium of heat and thermo-regulation, the chemical balance of water, the compounds of carbon and the electrolytes as well as the balance of blood circulation.

\section{TEMPERATURE OF ENVIRONMENT AND THERMO-REGULATION}

The thermos homeokineze or briefly denoted as homoeothermic is a condition that is characterized by the maintenance of relatively steady internal temperatures of organism, regardless of the changes in temperature of the surrounding temperature. The mammals and poultry are homothermous, that is, they can keep the body temperature at steady levels, regardless of fluctuations of temperature in the surrounding environment. The normal internal temperatures of the body of agricultural animals is at about $39^{\circ} \mathrm{C}$ while that of poultry at $41^{\mathrm{OC}}$.

Homothermous is retained from the equilibrium through the amount of metabolic heat produced by the animal (M), the amount of heat that is gained from the environment $(\mathrm{F})$ and that which is given off in the environment $(\mathrm{H})$, at a given time interval. That is the equilibrium between production of heat in the organism and the trading of heat between organism and environment.

\section{THERMICAL EXCHANGE BETWEEN THE ANIMALS AND ENVIRONMENT}

The animal may lose heat in the environment or otherwise gain it throught: radiation, convection, conductivity.

The heat transmission through radiation, convection and conductivity is triggered by the thermo gradients which can be located, gauged as heat; hence it is called a sensitive manner of heat transmission or sensible heat. Moreover the animal might easily lose heat in the environment through evaporation. The heat released from the evaporation of water through the hides or the breathing process is called the hidden heat or latent. The evaporation occurs because of the hydria gradient (mounting pressure of water evaporations) and the thermo ones. The heat that is released through evaporation might be gauged directly as a type of heat or indirectly through the amount of water evaporation released.

The departure of heat by way of evaporation through the hides (perspiration) or the breathing process (thermo polipness) is an efficient mechanism towards the protection of animals from the thermo overload in the course of the exposure to environmental possessing high temperatures.

By way of radiation, energy is transmitted between two bodies in a direct manner without the aid of an intermediary environment. The typical example of heat transmission from radiation is the warming of earth from the solar energy, without acting of the intermediary of atmosphere which is warmed later than the earth. During the radiation the radiating heat of the body is converted into the electro-magnetic waves; these waves are transmitted into space and are transformed into heat in the body that absorbs the radiation. The part of energy that is obtained through radiation that is not absorbed is otherwise emitted. The flux of heat transmitted through radiation expresses its dependence on the radiating area and the thermo gradient.

Convection is the transmission of heat by way of the molecular waves from an environment that is much hot into one which is cold, which is being done in two ways, free and strained (through ventilation). The transmission of heat with convection exists only in liquids and gases. The first elements which are in touch with the hot body are earned at first with convection (conductivity) and later with the heat distribution with convection as a result of the fluid movement (running) and which is the result of the changes in temperature in the fluid matter/material.

If we refer to a thing or body, the losses of heat through convection are due to differentiation of temperature between the body and environment $\left(t_{1}-t_{2}\right)$, the velocity of area in the environment $\left(V_{n}\right)$ and the characteristics of the body surface (form, dimension, profile, aerodynamics).

\section{HEAT TRANSMISSION AND CONDUCITIVITY}

Conduction is the transmission of the heat flux in a motionless environment. The energy is 
transmitted from particles to a particle during the contact established with the molecules. Each body is characterized from the coefficients of the thermo conductivity $(\lambda)$, which expresses the amount of energy being transmitted during two hours in an area of $1 \mathrm{~m}^{2}$ thickness of 1 meter and a temperature alteration of $1^{\circ} \mathrm{C}$ between the layers that trade heat.

The thermoconductivity of dry air is very weak. It should be highlighted that the thermoprotection made possible by the hair or feather protection is due to the area layer that are "imprisoned" between the hairs or feathers. The animals, bearing hairs and feather increase their thermoresistance (thermoisolation)

The thermoconductivity of water is high. Then, it is understandable that, a covering of soaked hairs and feathers has weak isolation strength. The exchange of heat with conductivity between the animal and the floor upon which they usually rest, depend on the following:

- type of flooring (with layer, no layer, type of layer used),

- its temperature,

- the body surface which is in direct contact with the floor.

The flux of heat that is being transmitted with conductivity might be calculated by means of the formula:

$$
Q_{p}=S_{p} \lambda\left(\frac{t_{1}-t_{2}}{d}\right)
$$

$Q_{p}$ - the thermo flux being conducted

$S_{p}$ - conductive effective surface of animal

$\lambda$ - coefficient of thermoconductivity of matter in contact with the animal

$t_{1}$ - the temperature of the mater in a point that is far from any contact with the animal

$t_{2}$ - matter temperature in the contact point with the animal

$d$ - distance between points where $d t_{1}$ and $t_{2}$ have been measured.

\section{IMPACT OF BEDDING MATERIALS ON THE FLUX OF CONDUCTED HEAT}

The exchange of heat with conductivity between the animal and the floor on which they rest depends on:
- type of floors and the type of the bedding material being used,

- temperature,

- body surface that is in contact with the floor.

\section{MATERIAL AND METHOD}

The purpose of the study is to prove the impact on the bedding material being used in the flux of heat conducted by piglets.

The study was administered based on the literature review and data in a series of monitoring conducted in the country in various pig-breeding farms. In the course of the study that focused on the impact of the bedding material in the flux of heat being transmitted from the piglets to the floor, their loss of heat with conductivity to the newlyborn litter of piglets, lying flat on the floor made of:

- concrete

- wood

- plastic

The environmental temperature was between $18-30^{\circ} \mathrm{C}$.

The coefficients of conductivity for these materials are respectively:

- 1,1 for the common concrete

- 0.125 for wood

- 0.025 for plastic.

The calculation of the heat loss from piglets to the floor, with the conductivity process, for the three types of floors, which had different coefficients of conductivity, was done on the basis of the formula cited above.

\section{RESULTS AND DISCUSSIONS}

The loss of heat with conductivity from the newly-born piglets lying on the concrete, wooden or plastic floors.

Concrete exhibits high conductivity when compared with wood and plastic.

The placing of a bedding material be it of wood or plastic between the animal and the floor leads to a significant reduction of heat loss with conductivity. 


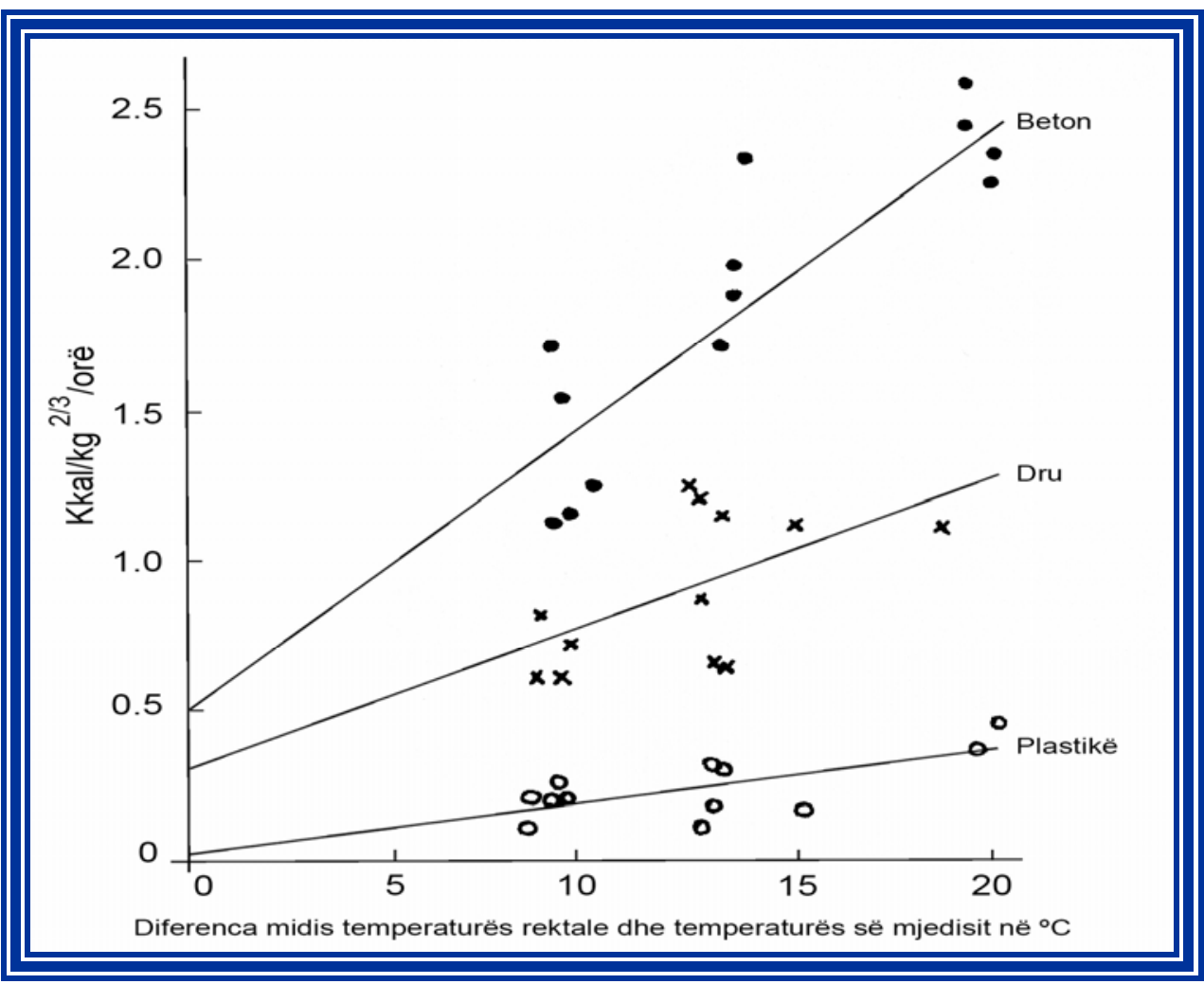

Moreover, from the studies conducted, it has been observed that the use of a bedding material of $2.5 \mathrm{~cm}$ over a concrete floor in a setting of $19^{\circ} \mathrm{C}$ allows for a reduction of heat loss with conductivity in the newly-born litter up to:

$-34 \%$ when the bedding material is a wooden frame; material;

$-59 \%$ when the bedding material is a plastic

$-73 \%$ when the bedding material is of wooden shavings;

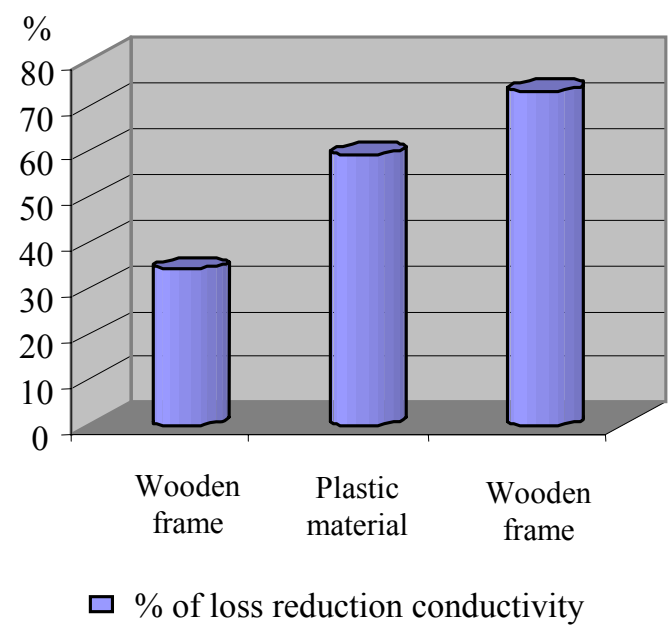

\section{ADAPTABILITY OF ANIMAL BEHAVIOR AGAINST THE HEAT LOSS WITH CONDUCTIVITY}

Apart from the use of various bedding materials so as to minimize the heat loss with conductivity, the animals through the adaptability of their behavior might modify in a big way the heat exchanges with the environment through the conductivity. Below we are providing a few examples of the adaptability of animal behavior in minimizing the heat loss through conductivity.

In piglets, lying flat on the stomach reduces by $50 \%$ the contact surface with the floor and by decreasing in doing the amount of heat loss with conductivity compared with the position of lying on the side.

In certain groups of animals (say in a collective pen) placed in a cold environments (temperature under the optimal), we see a behavior pattern characteristic of the group (huddling together, pressing against one another), which reduces the surface area in contact with the floor and the environmental air.

Another way of adaptability of behavior so as to reduce the heat transmission is the one in the 
form of the "ball", which indicates an uncomfortable situation in the shed.

In species that have no hair covering we observe a marked tendency of fat rolls created under the hides that acts as a perfect isolation.

The vaso-construction phenomenon (constriction of blood vessels) might reduce "the shift" of temperature between the body area in contact with the floor and the floor that is it leads to a calorie flux from body to the floor.

\section{CONCLUSIONS}

The conducted thermo flux, aside from dependence on the efficient conductive area of animal and the thermo gradient has a sensitive dependence on the bedding material that is utilized and this is attributed to the various coefficients of the conductivity, of the bedding material that is used in the poultry and animal husbandry.

The placing of the bedding material between the animal and the floor reduced significantly the heat loss through conductivity.
Concrete, while compared to wood and plastic presents the highest conductivity.

The use of a bedding material of some $2.5 \mathrm{~cm}$ over a floor of concrete, wood allows for the reduction in the heat loss with conductivity in the newly-born litter in: $34 \%$ when the $73 \%$ when the bedding material is of wood shavings.

These effects will have to be closely considered in the animal breeding process so as to avert the excessive energy loss in the form of heat; this would benefit the protection of animal health as well as the high conversion food index.

\section{REFERENCES}

[1] Shoshi Natalia (2004): Higjiena Veterinare, 1, UB Tiranë.

[2] Aghina C., Maletto S., Maletto.R. (1999): La gestione igienico-sanitario degli allevamenti, Reda, Roma.

[3] Galiardi. G. (1993): Controllo dello stres, Brescia.

[4] Glauka, Torrissi (1996): Igiene Zootecnika, Bologna. 